\title{
Crowdinvesting in entrepreneurial projects: disentangling patterns of investor behavior
}

\author{
Maximilian Goethner • Sebastian Luettig • Tobias \\ Regner
}

Accepted: 19 January 2020 / Published online: 26 March 2020

(C) The Author(s) 2020

\begin{abstract}
Crowdinvesting emerged recently as an alternative way of funding for start-up projects. Our dataset consists of 16,666 investments made at Companisto, one of the largest crowdinvesting platforms in Europe. Using cluster analysis based on individual investment decisions, we find that crowdinvestors differ in their investment strategies and motivations. We can distinguish three types of crowdinvestors: Casual Investors, Crowd Enthusiasts, and Sophisticated Investors. The types also vary in their response to project quality signals, project-related information reducing the degree of uncertainty, and social influence by fellow investors. We conclude that crowdinvestors are anything but a homogeneous group. Instead, they are motivated by different factors and respond to different signals when making investment decisions.
\end{abstract}

Keywords Crowdinvesting · Entrepreneurial finance · New ventures $\cdot$ Cluster analysis $\cdot$ Social influence . Signaling

M. Goethner $(\bowtie) \cdot$ S. Luettig $\cdot$ T. Regner

School of Economics and Business Administration, Friedrich Schiller University Jena, Carl-Zeiss-Str. 3, 07743 Jena, Germany e-mail: maximilian.goethner@uni-jena.de

\section{S. Luettig}

e-mail: basti.luettig@gmail.com

T. Regner

e-mail: tobias.regner@uni-jena.de
JEL classifications $\mathrm{G} 23 \cdot \mathrm{G} 41 \cdot \mathrm{L} 26$

\section{Introduction}

Early-stage start-ups are confronted with considerable difficulties in attracting external finance. A barrier to the acquisition of financial resources arises from imperfections in capital markets, which are conventionally attributed to the existence of information asymmetries (Carpenter and Petersen 2002; Cassar 2004; Colombo and Grilli 2007). Specifically, entrepreneurs possess more information about their abilities and the prospects of their new business than outsiders. As start-ups often lack assets to provide as collateral, and because they lack the financial history and the track record necessary to establish their reputation, investors cannot readily observe venture quality and may thus be reluctant to provide funding (Shane and Stuart 2002).

Recent advancements in information and communication technologies (ICTs) have led to financial innovations that ease the way in which capital demand meets supply and thus improve the efficiency of capital markets (Agrawal et al. 2014). Among these innovations, crowdfunding $(\mathrm{CF})$ is emerging as one prominent financing alternative for early-stage entrepreneurial projects (Block et al. 2018a; Bruton et al. 2015).

The recent phenomenon of CF promises to be a new way to match entrepreneurs looking for funds and potential financiers. In contrast to traditional financiers, $\mathrm{CF}$ allows funds to be raised by rather small amounts from a large group of individuals, the "crowd." CF grew 
exponentially in the last years (Massolution 2016) giving reason to believe that it will develop into an important funding channel in the future.

The success of CF stimulated an increasing body of research devoted to determinants of the individual decision to fund a specific project. This research highlights the significance of quality signals (Ahlers et al. 2015; Li et al. 2016; Ralcheva and Roosenboom 2016; Nitani and Riding 2017; Piva and Rossi-Lamastra 2018; Bapna 2019), social influence (Herzenstein et al. 2011; Zhang and Liu 2012; Lee and Lee 2012; Hekman and Brussee 2013; Vulkan et al. 2016; Crosetto and Regner 2018; Hornuf and Schwienbacher 2018; Vismara 2018), and social capital (Mollick 2014; Colombo et al. 2015; Giudici et al. 2018; Vismara 2016). Using data from Kickstarter, a pre-ordering based CF platform, Lin et al. (2014) demonstrate that different types of crowdfunders can have different motives of backing a project leading to different funding strategies. Also, the information on which crowdfunders base their individual decision, ranging from quality signals to information about the activity of other crowdfunders, are not alike across the different types.

Our paper builds on the approach of Lin et al. (2014) but focuses on equity-based CF or crowdinvesting (CI). In the USA, specific rules of the Jumpstart Our Business Start-ups (JOBS) Act were implemented only in May 2016. Thus, only limited US data on CI exists so far. By analyzing data from Companisto, one of the largest CI platforms in Europe, our study is the first, to the best of our knowledge, to provide valuable insights about crowdinvestor heterogeneity. Our dataset consists of 16,666 investments into 28 projects made by 7474 funders at Companisto.

Our analysis shows that investors differ in their motivations and investment strategies. We identify the following three types: a relatively small group is very active and experienced ("Sophisticated Investors"), a sizable group of funders is motivated by pro-social/ community factors ("Crowd Enthusiasts"), and the majority of funders seem mostly concerned about monetary returns ("Casual Investors"). Furthermore, these identified crowdinvestor types react in distinct ways to project quality signals sent by the creators of start-up projects and information observed from the investment decisions of fellow crowdinvestors, when selecting among investment opportunities. These insights about investor heterogeneity contribute to a better understanding of crowdinvesting with practical implications for platforms and entrepreneurs.
The remainder of this paper is structured as follows. Section 2 discusses the related literature, and Sect. 3 describes our data source, the crowdinvesting platform Companisto. We derive our typology of crowdinvestors in Sect. 4. In Sect. 5, we explore differences in investment behavior among these investor types. Section 6 concludes.

\section{Background literature}

To address the problems of information asymmetry involved in the financing of entrepreneurial projects, professional investors individually design their financing contracts (Gompers and Lerner 2001; Wong et al. 2009). This allows them to separate the allocation of cash flow rights, voting rights, board rights, liquidation rights, and other control rights such as staged capital infusion. As crowdinvesting (CI) caters to a large number of investors, tailor-made contracts can hardly be implemented resulting in the use of highly standardized contracts. Thus, CI contracts provide only little ex-ante protection against problems of asymmetric information (Kortleben and Vollmar 2012; Hornuf and Schwienbacher 2016). Since most crowdinvestors are less experienced in evaluating the actual value of a business idea compared to professional investors, the problem of information asymmetry is especially pronounced in the setting of CI. Even if some securities regulators took initial steps towards the alleviation of these issues (Hornuf and Schwienbacher 2017), there is still a great concern about the possible exploitation of less sophisticated investors (Hildebrand et al. 2017).

In particular, the identification of valuable investment opportunities and the monitoring of the investee remain a key challenge in CI (Agrawal et al. 2014). Against this backdrop, recent research on $\mathrm{CF}$ and $\mathrm{CI}$ has been devoted to understanding the identification of worthwhile investments under asymmetric information between investor and campaign initiator. One part of this literature addresses the entrepreneurial perspective. For example, Mollick (2014) conducted a study on the determinants of success and failure of CF projects listed on Kickstarter. He found that project quality signals such as a video description of the project are correlated to fundraising success. Moreover, the size of an entrepreneur' social network is found to be a determinant of successful fundraising. Similarly emphasizing the beneficial role of social capital, Hekman and Brussee 
(2013) and Giudici et al. (2018) stress the importance of social networks for signaling project quality to potential investors.

The first study trying to assess the crowd's response to quality signals within CI has been conducted by Ahlers et al. (2015) using data from ASSOB, an Australian CI platform on which entrepreneurs sell equity shares to their investors. Their findings support the importance of human capital (proxied by the number of board members in the management team and the share of board members holding an MBA degree) as an effective quality signal that increases the number of investors. Likewise, providing financial forecasts in their offering documents (e.g., a financial disclaimer stating forecasts of future earnings) is positively correlated with the number of investors. Moreover, an increase in the percentage of equity offered to investors resulted in a lower expected number of investors.

Subsequent studies confirm the importance of human capital as an effective quality signal for CI. Piva and Rossi-Lamastra (2018) analyze data from an Italian platform (SiamoSoci) and find that entrepreneurs' business education and their experience are success determinants. Nitani and Riding (2017) study data from four European platforms and confirm the relevance of entrepreneurs' education. Using data from the Chinese site Dajiatou, also Li et al. (2016) empirically confirm the importance of human capital.

Another potential quality signal is certification by a third party. Ralcheva and Roosenboom (2016) analyze data from Crowdcube and find that backing by a business angel, grants, and protected intellectual property rights (via patents, trademarks, or copyrights) significantly increase success chances. Bapna (2019) conducts a randomized experiment at an anonymized CI platform and finds that certification by an expert intermediary increases the tendency to invest, however, only when combined with other signals (a prominent affiliate or social proof).

Hornuf and Schwienbacher (2018) investigate the reaction of crowdinvestors following the investment decisions of their peers. They document the presence of general herding behavior in their analysis of individual investment decisions among 60 CI campaigns, covering investments on Seedmatch and Innovestment. Moreover, Vulkan et al. (2016) analyze data from SEEDRS and show that having a strong start is a vital campaign success determinant. Broadening the understanding of social influence in the context of CI,
Vismara (2018) demonstrates how information cascades among investors can form. He finds that a higher number of investors within the first 5 days of a campaign to increase the number of subsequent investors, the total funding amount, and hence the probability of a successful funding campaign. The number of early investors turned out to be significantly higher when public profile investors have been present within the first 5 days of a campaign. Relatedly, Kim and Viswanathan (2018) identify investors on Appbackr, a CF platform for mobile applications, as experts if they have already developed an app or if they have prior investment experience. They show that investors without specialized expertise emulate the investment decision of these experts.

Finally, some studies investigate the role of withincampaign communication signals. Hornuf and Schwienbacher (2018) find that investors posting comments on the product or market have a positive impact on the number of investments the next day. Block et al. (2018a) show that especially updates about new developments of the start-up have a positive effect on funding. Also, Li et al. (2016) report the importance of project updates as a success determinant.

Lin et al. (2014) identify four distinct groups of crowdfunders on Kickstarter based on their motivations to back specific projects: active backers, trend followers, the altruistic, and the general crowd. Active backers are found to be mainly motivated by social and reputational benefits. Altruistic backers appear to be less risk-averse, primarily motivated by supporting the idea of a project regardless of its popularity or potential risk of failure, in contrast to trend followers. Additionally, these four types of investors also differ in their responses to signals of social capital and social influence. For instance, when it comes to the funding decision, trend followers and active backers are more likely to back projects which have already been backed by a larger number of other funders than the group of altruistic investors. Referring to social capital, measured as the number of projects backed by the project creators themselves, trend followers are less likely to respond to this type of quality signal compared to the general crowd. See Ryu and Kim (2016) for related evidence based on survey data.

These findings give reason to assume that the "crowd" is not a homogeneous community and some studies on crowdinvesting started to segregate the crowd. Hervé et al. (2019) and Mohammadi and Shafi 
(2018) show that female crowdinvestors behave more risk averse than male ones, while Hornuf and Schmitt (2016) and Günther et al. (2018) show that a local bias exists among crowdinvestors. Furthermore, Wallmeroth (2019) reports that large pledges (more than EUR 5000) at Companisto make up 3.2\% of all pledges but account for about half of the raised funds. Our study builds on this research and goes a step further as it systematically categorizes investors based on their characteristics. We identify distinct investor types and explore how these different types make their investment decisions. As stressed by Mochkabadi and Volkmann (2018) in a recent survey article on crowdinvesting, such a typology of investors should provide valuable insights about the crowd.

\section{Dataset}

Our unique dataset is hand-collected from the website of the German CI platform Companisto. Founded in 2012, Companisto is one of the leading CI platforms in Europe and the one currently with the largest market share in Germany (Crowdfunding-Monitor 2017). By the end of December 2014, the platform had 39,007 registered users and gathered a total of EUR 21,253,840 for the 44 projects it hosted. A minimum ticket size of EUR 5 allows essentially anyone to partake in a start-up project. Companisto pools the investments of the crowd via a special purpose entity, Companisto Venture Capital GmbH. Under the "all-or-nothing" model of crowdinvesting, project creators set a funding goal and do not receive any pledges unless that goal is reached. In case the start-up project fails to meet the funding goal, Companisto Venture Capital GmbH returns the pledged money to the would-be investors. Moreover, investment shares in start-up projects are allocated on a first-come, first-serve basis. Accordingly, project creators set an overall funding limit, which is typically higher than the funding goal, and stop selling securities when they reach this limit. From the perspective of the investors, losing the principal amount invested represents the highest risk they are exposed to (for example, in the case of insolvency of a start-up project).

The objective of our study is to identify different types of crowdinvestors showing different preferences and to reveal how these different crowdinvestor types make their backing decisions according to their preferences. For this purpose, the data collection process covers every investment that has been made throughout all the campaigns (including the amount of each investment and the date of investment) in addition to data about the campaigns themselves (e.g., the business idea, awards won, the involvement of external financiers, financial statements, the education of the project creators, the updates made by the project creator, and comments that were left by investors).

We only consider funding campaigns which ran for the first time on Companisto. Second time funding campaigns, representing follow-up financing, have a strong tendency to attract funders due to their attention gathered in the first financing round. This might affect investors' choice set of alternatives and their investment decision more profoundly than their preferences do. For this reason, we excluded investments in second run campaigns in order to avoid potential distortion of the analysis. Thus, the final dataset that is used for the empirical analysis comprises information on 16,666 investments made by 7474 funders in 28 start-up projects listed on Companisto from June 6, 2012 to December $21,2014{ }^{1}$

All projects reached their goal, and have thus been successfully funded, within 8 to 123 days. The average campaign attracted 595 investors, received EUR 216,878, made 12 updates, and received 134 comments. The average investment is EUR 364, and it occurred 20 days after the start of the campaign. The average investor invested EUR 402.28 in 2.23 projects and commented 1.6 times.

Our analytical approach is to use these data for (i) a cluster analysis that categorizes investors into different types and (ii) then test whether the resulting types respond distinctly to project quality signals of start-up projects and information observed from the investment decisions of fellow crowdinvestors. For the cluster analysis, we use investor-level variables, see Sect. 4.2.1 for details. Our analysis of the response to quality signals considers data at the investment level; see Sect. 5.3 for further description of the respective variables. Table 1 displays descriptive statistics of the 28 CI projects, as well as summary statistics at the investor and investment level.

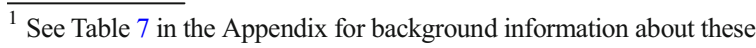
projects.
} 


\section{Typology of crowdinvestors}

Crowdinvestors usually do not have the financial sophistication and investment experience of professional entities or individuals, such as banks, venture capitalists, or business angels (Freear et al. 1994). Hence, they are likely to evaluate start-up projects and creators in different ways. In the following, we identify determinants of a crowdinvestor's funding decision helping us to identify an investor typology.

\subsection{What drives crowdinvestors to fund a project?}

In their multidisciplinary review of the crowdfunding literature, Gleasure and Feller (2016) distinguish between the following motivations among crowdinvestors: paying for financial/material benefits, for social benefits, and for participation.

Funders engaging in CI receive equity or equity-like arrangements in return for their investment. Thus, the expectation of financial benefits of an investment is a natural motivator for their engagement. Moysidou and Spaeth (2016), for instance, report that perceived financial benefits play a dominant role in the decision making of crowdinvestors.

Besides extrinsic factors that may explain contributions of the crowd, funders may be intrinsically motivated, for instance, by social benefits. Gerber et al. (2012) document that funders participate on CF platforms, because they like to support creator and cause. They want to be of valuable assistance in the entrepreneur's effort to realize the project idea. Funders supporting the cause may have an interest in securing the creativity and originality of the idea as they are afraid that with tapping into traditional channels of financing the creator's idea has to be compromised in order to get the product out. Altruistic behavior has also been found by Galak et al. (2011) studying lenders on the crowdlending website Kiva.org. In the context of CI, Bretschneider and Leimeister (2017) provide survey evidence that "simply liking a venture" is a positive determinant of the investing decision. Similarly, Daskalakis and Yue (2017) find that interest and excitement are the top drivers in a survey of European crowdinvestors. Also Cholakova and Clarysse (2015) confirm non-financial motives among crowdinvestors, although their impact on the decision to invest seems smaller in comparison to monetary motives.
A distinct intrinsic motivation is participation. Belleflamme et al. (2014) propose that crowdfunders experience "community benefits" when they pledge to a project of their liking. Gerber et al. (2012) find that crowdfunders are motivated by being part of a trusting and creative community. The relevance of such drivers has also been confirmed within other online communities by Kraut and Resnick (2011). Moreover, survey responses in Bretschneider and Leimeister (2017) indicate that crowdinvestors are motivated by the possibility to participate in and influence the development process of the start-up's product. Finally, Vismara (2019) uses the introduction of a regulatory framework in the UK that distinguishes between professional and restricted investors. Professionals aim to maximize their funds, while the latter follow a community logic.

\subsection{Cluster analysis}

We investigate whether the "crowd" can be differentiated into distinct investor types. For this purpose, we perform an explorative cluster analysis sorting crowdinvestors based on similarities in their previous investment histories. To determine investor profiles and investment strategies, we consider the three proposed motivations among crowdinvestors (i.e., financial, social, community benefits) and their experience/sophistication. The input variables for the cluster analysis are described in the following. Table 1 displays their descriptive statistics.

\subsubsection{Variables}

Projects indicates the number of investment projects in a crowdinvestor's portfolio during the period of analysis. This variable reflects investor experience and activity as well as the degree of portfolio diversification (Lin et al. 2014).

Invested amount represents the average of all investments made by a crowdinvestor. The average investment is indicative of investor knowledge and expertise (Hornuf and Schwienbacher 2018). More sophisticated and experienced investors may conduct more extensive due diligence of a start-up project. They naturally invest higher amounts as the transaction costs of examining the start-up make smaller investments unprofitable. Both variables, Projects and Invested amount, are used in the cluster analysis to capture the influence of experience on crowdinvestor behavior. The variable Projects 
Table 1 Descriptive statistics of the study variables

\begin{tabular}{|c|c|c|c|c|c|c|c|}
\hline & Count & Unit & Mean & SD & Min & Median & Max \\
\hline \multicolumn{8}{|l|}{ Project-level variables } \\
\hline Funding duration & 28 & Days & 65.21 & 33.72 & 8 & 60.50 & 123 \\
\hline Funding target & 28 & $€$ & $28,571.43$ & 8908.71 & 25,000 & 25,000 & 50,000 \\
\hline Funding amount & 28 & $€$ & $216,877.90$ & $203,665.10$ & 41,290 & $127,767.5$ & 940,650 \\
\hline $\mathrm{PhD}$ & 28 & Dummy & 0.14 & 0.36 & 0 & 0 & 1 \\
\hline Team members & 28 & Integer & 4.11 & 1.47 & 2 & 4 & 8 \\
\hline Awards & 28 & Dummy & 0.18 & 0.39 & 0 & 0 & 1 \\
\hline Financial forecast & 28 & Dummy & 0.21 & 0.42 & 0 & 0 & 1 \\
\hline Ties & 28 & Dummy & 0.57 & 0.50 & 0 & 1 & 1 \\
\hline Innovativeness & 28 & Dummy & 0.29 & 0.46 & 0 & 0 & 1 \\
\hline Investors & 28 & Integer & 595.20 & 303.60 & 264 & 475 & 1621 \\
\hline Updates & 28 & Integer & 12.14 & 4.96 & 4 & 11.50 & 25 \\
\hline Comments & 28 & Integer & 134.35 & 86.03 & 40 & 97.50 & 325 \\
\hline \multicolumn{8}{|l|}{ Investment-level variables } \\
\hline Investment amount & 16,666 & $€$ & 364.36 & 1069.14 & 5 & 100 & 25,000 \\
\hline Days after project start & 16,666 & Days & 20.08 & 26.90 & 0 & 8 & 441 \\
\hline \multicolumn{8}{|l|}{ Investor-level variables } \\
\hline Projects & 7474 & Integer & 2.23 & 2.93 & 1 & 1 & 28 \\
\hline Invested amount & 7474 & $€$ & 402.28 & 1192.40 & 5 & 100 & 25,000 \\
\hline Investors & 7474 & Integer & 794.48 & 361.93 & 264 & 702 & 1621 \\
\hline Comments & 7474 & Integer & 1.60 & 6.74 & 0 & 0 & 219 \\
\hline Innovativeness & 7474 & Rational & 36.65 & 42.30 & 0 & 16.67 & 100 \\
\hline
\end{tabular}

also indicates a crowdinvestor's focus on financial benefits (i.e., portfolio diversification as a risk-reducing strategy).

Investors is the average number of investors per project in the investor's portfolio. The number of prior investors among funded projects can reveal insights into an investor's sense of community and its perceived benefits. Crowdinvestors enjoying community benefits do so because they put their hearts together striving for a common purpose (Gerber et al. 2012). In the cluster analysis, the variable Investors thus allows us to assess whether a crowdinvestor is motivated by being part of a project.

Comments is the number of comments an investor posted on Companisto. Posted comments include, for example, responses to updates of the project creators or comments and questions of other investors. Such comments may contain information about the product or market development, possible product improvements or even the offer of personal help to the project creators. Comments are commonly used to evaluate an individual crowdinvestor's engagement in the CI community (Mollick 2014; Hornuf and Schwienbacher 2018). We use the variable Comments as an indicator of experience and of a crowdinvestor's drive to participate in a start-up community.

Innovativeness captures the innovativeness of an investor's portfolio. It measures the share of innovative start-up projects relative to the total number of funded projects. We consider a start-up project as innovative if (1) intellectual property protection, such as patents or trademarks, has been applied for, (2) the start-up pursues a significant R\&D strategy, (3) the start-up serves a market in which there are no direct competitors, and (4) the start-up is the only supplier of its service or product on the market. Information to evaluate the innovativeness of a start-up project are taken from the project description on Companisto. Prior research shows that more innovative start-up projects raise higher amounts of capital and account for a higher number of investors than less innovative ones (Le Pendeven 2016). In the cluster analysis, we employ the variable 
Innovativeness to distinguish pro-social motivations as driver of engagement in CI. Crowdinvestors with a higher share of innovative projects in their portfolio might be driven by the desire to support projects that otherwise would suffer from severe funding gaps.

\subsubsection{Method}

Cluster analysis is a multivariate technique that sorts different objects into groups by maximizing withingroup similarities and between-group differences. The identification of clusters is thus empirically based instead of guided by theory.

In this study, we used a two-stage clustering procedure where a hierarchical clustering was employed as a prior step to determine the appropriate number of clusters for subsequent non-hierarchical clustering (Ketchen and Shook 1996). This approach is shown to lead to superior clustering solutions and to increase the validity of the final clusters obtained (Milligan 1980; Punj and Stewart 1983). For both stages of the clustering procedure, we calculated distance matrices using the Euclidean distance measure.

In the first stage, a pre-clustering with the single linkage method was processed to eliminate potential outliers (Jiang et al. 2001). Twenty-eight crowdinvestors have been identified as outliers and were excluded from further analysis. The main procedure was performed using Ward's minimum-variance method. This hierarchical method treats every object as a separate cluster at the beginning of the algorithm. The clusters are then successively joined together into groups until only a single cluster remains. The objective of Ward's method is to join two clusters at each step such that the variance for the joined cluster is minimized (and the variance between clusters is maximized). Ward's method has been shown to be superior to alternative approaches and to form very homogeneous clusters (Punj and Stewart 1983; Milligan and Cooper 1985).

In the second stage of the clustering procedure, we performed a non-hierarchical $k$-means clustering using the same dataset. With $k$-means clustering, objects are iteratively classified based on their distance to some initial starting points of dimension $k$. While some $k$ means methods use randomly selected starting points, we employ the centroids of the initial cluster solution of Ward's method for this purpose (Ketchen and Shook 1996). Using this non-hierarchical procedure, we identify three clusters of crowdinvestors.
Finally, a comparison of the means of the input variables obtained from Ward's method with those of the $k$-means algorithm did not show any qualitative differences. Also, the application of the above described two-stage procedure for a randomly split sample has led to the same results as those derived from using the full sample. Thus, we find support for the reliability of the three-cluster solution.

\subsubsection{Results}

The results are presented in the dendrogram in Fig. 1 in the Appendix. Starting from the bottom, more and more clusters are grouped together when higher levels of dissimilarity (or lower levels of similarity) are accepted. A visual inspection of the dendrogram suggests three different groups of crowdinvestors.

In Table 2, we report the final cluster solution derived from the $k$-means clustering procedure, providing descriptive statistics for the input variables included in the cluster analysis for each of the identified clusters. We explore differences between the identified clusters using ANOVA and post-hoc Duncan tests. The distinct characteristics of crowdinvestors belonging to the three clusters can be described as follows.

Cluster 1 Crowdinvestors in cluster 1 comprise $61.29 \%$ of the sample. These individuals distinguish themselves from the rest of the crowdinvestors through the highest number of funded projects (2.56 projects on average, compared to an average of 1.69-2.01 for the other clusters), the lowest amount invested per project (EUR 156.57 on average, which is approximately half the average amount invested by the full sample of crowdinvestors), and the lowest share of innovative projects $(27.43 \%$, compared to more than $40 \%$ for Clusters 2 and 3). Also, with 566.92 investors per project, the average number of project backers tends to be the smallest (compared to the more than 900 investors for the other clusters). To sum up, crowdinvestors in cluster 1 tend to be relatively risk-averse investing small amounts in less innovative, less risky projects. Besides, the small number of project backers suggests that community aspects play a small role when making their investment decision. Cluster 1 seems to primarily pursue own financial interests while trying to keep the probability of financial losses small. We label this group the Casual Investors. 
Table 2 Three-cluster solution for the explorative cluster analysis

\begin{tabular}{|c|c|c|c|c|c|c|c|c|}
\hline \multirow{3}{*}{$\begin{array}{l}\text { Clustering variables } \\
\text { Projects }\end{array}$} & \multicolumn{6}{|c|}{ Mean values (SD) } & \multirow{3}{*}{$\frac{{\text { ANOVA } F \text { value }^{\mathrm{a}}}}{74.32 *}$} & \multirow{3}{*}{$\begin{array}{l}\text { Post hoc mean difference } \\
\text { test (Duncan) }^{\mathrm{b}} \\
1>2,3\end{array}$} \\
\hline & \multicolumn{2}{|c|}{ Cluster $1(n=4564)$} & \multicolumn{2}{|c|}{ Cluster $2(n=2568)$} & \multicolumn{2}{|c|}{ Cluster $3(n=314)$} & & \\
\hline & 2.56 & $(3.50)$ & 1.69 & $(1.41)$ & 2.01 & $(2.59)$ & & \\
\hline Invested amount & 156.57 & $(206.30)$ & 329.07 & (387.39) & 3298.55 & $(1400.06)$ & $9052.27 *$ & $3>1,2 ; 2>1$ \\
\hline Investors & 566.92 & (153.09) & 1182.49 & $(274.14)$ & 915.19 & $(387.29)$ & $6733.81 *$ & $2>1,3 ; 3>1$ \\
\hline Comments & 1.69 & $(7.06)$ & 1.36 & $(6.02)$ & 2.26 & $(7.54)$ & $3.52 * *$ & $1,3>2$ \\
\hline Innovativeness & 27.43 & $(37.80)$ & 52.33 & $(44.80)$ & 41.84 & (44.03) & $311.56^{*}$ & $2>1,3 ; 3>1$ \\
\hline Population (\%) & \multicolumn{2}{|l|}{61.29} & \multicolumn{2}{|l|}{34.49} & \multicolumn{2}{|l|}{4.22} & & \\
\hline Cluster label & \multicolumn{2}{|c|}{ Casual Investors } & \multicolumn{2}{|c|}{ Crowd Enthusiasts } & \multicolumn{2}{|c|}{ Sophisticated Investors } & & \\
\hline
\end{tabular}

$\mathrm{a} * p<0.001 ; * * p<0.05$

${ }^{\mathrm{b}} p<0.05$

Cluster 2 This group comprises $34.49 \%$ of the sample. With only 1.69 investments and 1.36 posted comments on average, crowdinvestors in cluster 2 seem to be the least active group of investors on Companisto. However, they emphasize funding innovations; on average $52.33 \%$ of the backed projects are innovative, representing the highest share among the three clusters. Given that these crowdinvestors appear to be less concerned about the higher degree of uncertainty involved in funding innovations, they may be driven by prosocial factors and community benefits. This group of investors might possess a strong sense of community, as may be indicated by the highest number of investors per project (i.e., 1182.49 project backers on average). Sharing the goal of funding a specific project with many others increases the chances of success while providing investors also with a community benefit and the feeling to be a valuable part of an "uplifting force." We label these individuals the Crowd Enthusiasts.

Cluster 3 The third cluster represents the smallest group of crowdinvestors ( $4.22 \%$ of the sample). This group stands out from the other clusters for the average funding amount of EUR 3298.55. These investors are likely to have more experience and to have undertaken thorough due diligence, making their relatively large investments economically reasonable. They know how to assess the quality of projects and their creators and where to access more complex information about the projects that are not provided in the project descriptions. Both their substantial investments and their active participation, as indicated by posting the most comments (on average 2.26), further suggest a relatively strong dedication to the funded project as compared to investors in clusters 1 and 2. We label investors of cluster 3 the Sophisticated Investors.

\subsubsection{Robustness check}

We conduct robustness checks to test the sensitivity of the identified investor typology with respect to the size of the sample of crowdinvestors considered for the cluster analysis. In particular, we re-run the cluster analysis with the same set of input variables but using different investor subsamples. Subsamples are constructed according to the timing of the investment decision. In three separate robustness checks, we restricted the cluster analysis to investors who invested in the first nine, 12 and 14 projects listed on Companisto. In all three analyses, our typology of crowdinvestors turned out to be robust. This cluster structure further remained robust to a final subsample specification where we restricted the cluster analysis to investors with at least two investments (i.e., excluding investors who only invested once on Companisto).

\section{How do crowdinvestor types differ in their investment decision?}

Building upon the cluster analysis results, we now attempt to validate our typology of crowdinvestors. We develop a set of hypotheses proposing how these distinct crowdinvestor types may react to project quality signals of entrepreneurs, project-related information reducing the degree of uncertainty and social influence by 
fellow investors when making their investment decision. We consider four relevant mechanisms identified by the entrepreneurial finance literature: human capital of project creators, third-party certifications, financial projections and observed behavior of other investors.

\subsection{Hypotheses}

Project quality may be signaled to potential investors by the human capital of project creators. Generally, human capital encompasses an individual's skills and knowledge acquired through education, on-the-job training and other types of experience which may increase one's productivity at work (Becker 1964). Entrepreneurship researchers have investigated the influence of human capital on entrepreneurial success for over three decades (Unger et al. 2011). The importance of entrepreneurs' human capital is further highlighted by prior studies that suggest managerial skills and experience are among the selection criteria that are most frequently used by venture capitalists (Baum and Silverman 2004; Zacharakis and Meyer 2000).

Similarly, crowdinvestors perceive the qualifications and education of project creators as a reliable signal of project quality, see Ahlers et al. (2015), Li et al. (2016), Nitani and Riding (2017), and Piva and Rossi-Lamastra (2018) for related empirical evidence. Therefore, we expect a general tendency of crowdinvestors to fund projects of creators with higher levels of human capital. Due to their distinct profiles, however, such quality signals may not be perceived as equally important across the different types of crowdinvestors. In particular, Crowd Enthusiasts and Sophisticated Investors tend to invest more in innovative projects than Casual Investors. Since innovative investments reflect a higher degree of uncertainty regarding both the probability and magnitude of economic returns, Crowd Enthusiasts and Sophisticated Investors might more strongly rely on signals of project quality related to human capital of the entrepreneurs than Casual Investors. Therefore, we hypothesize:

Hypothesis 1: Crowd Enthusiasts and Sophisticated Investors are more likely to invest in projects whose creators signal human capital than Casual Investors.

Besides signals provided by the project creators, potential investors may also look for external certifications of project quality. In the context of CI, Ralcheva and Roosenboom (2016) analyze three signaling mechanisms, in which a third party is involved. Ventures with business angel backing, grants, and intellectual property rights have significantly increased chances of success. Furthermore, Bapna (2019) studies the effect of certification by expert intermediaries on the tendency to invest.

Again, taking investor heterogeneity into account, we expect such external certifications not to be of equal importance to all crowdinvestor types. We argue that entrepreneurs' external certifications about project quality are relatively more important to Casual Investors. Sophisticated Investors tend to be experienced and more knowledgeable regarding reliable indicators of future project success (e.g., business plan, patents held, industry outlook). They know how to gather this information elsewhere in case it is not provided by the project creators, which makes them less likely to rely on thirdparty certifications of project quality. Crowd Enthusiasts' are less concerned with making a profit; instead, they have the desire to support project creator and cause. They tend to invest in a project if the business idea convinces them. Whether projects provide external certifications then seems to be of secondary relevance for them. Thus, we propose the following hypothesis:

Hypothesis 2: Casual Investors are more likely to invest in projects that provide third-party certifications than Crowd Enthusiasts and Sophisticated Investors.

Informational asymmetries between investor and entrepreneur are a key challenge in CI (Agrawal et al. 2014). If the degree of information asymmetry is too high and the supply of projects of inferior quality is relatively higher than the supply of good quality projects, markets of venture financing, such as CI, might even collapse. In order to attract funding, entrepreneurs need to provide reliable information that helps reduce the degree of uncertainty regarding the quality of the start-up project (Ireland et al. 2003). For instance, disclosing financial projections facilitates potential investors forming of expectations of the start-up's future returns, detailing the risks and opportunities of the investment. See Michael (2009) for similar evidence from the franchise sector and Ahlers et al. (2015) who find a positive link between the 
disclosure of financial information (like roadmaps) and the funding success of CI campaigns.

Following previous research, there should also be a positive relationship between the provision of financial projections and the likelihood that a project receives investments in our data. We argue however that the assessment of financial projections disclosed by entrepreneurs differs across crowdinvestor types. Crowd Enthusiasts' portfolios contain the highest share of innovative projects. In order to make their investment choices, they may focus on a project's idea, its vision, while they may put less emphasis on expected economic outcomes. By contrast, Casual Investors are mainly motivated by financial interests. They tend to keep the probability of financial losses small by diversifying their investments among less innovative (and therefore less risky) projects. Thus, Casual Investors are likely to strongly rely on information directly related to possible future outcomes most strongly. This assumption is in line with other research demonstrating that disclosed financial information is particularly appealing to riskaverse investors (Epstein and Schneider 2008). Sophisticated Investors tend to have a professional approach to investing. While they are open to risky investments in innovative projects, they also consider provided financial projections when they decide on an investment. Accordingly, we hypothesize:

\section{Hypothesis 3: Casual Investors and Sophisticated Investors are more likely to invest in projects that provide information about financial projections than Crowd Enthusiasts.}

Recent research on CF and CI stresses the role of social influence for the funder's decision to invest. The availability of information concerning the timing and the number of investments are found to be critical factors affecting the investment behavior of subsequent funders. In this context, empirical findings have been related to economic models of herding behavior (Herzenstein et al. 2011; Lee and Lee 2012; Zhang and Liu 2012; Colombo et al. 2015; Crosetto and Regner 2018; Vismara 2018) or substitution (i.e., crowding-out; Burtch et al. 2013). Lin et al. (2014) find that whether crowding-out or herding takes place depends on the backer's motivation to engage in CF. They show that with an increasing number of backers the probability decreases that a project is chosen by users with altruistic motives to participate in CF. Likewise, altruists do not seem to imitate the investment decision of experienced investors. On the contrary, risk-averse and reward-driven crowdfunders are found to imitate the decision of others, resulting in general herding behavior.

Based on these findings, we expect different responses to observed peer behavior along the crowdinvestor typology. In particular, among the identified crowdinvestor types, we expect Crowd Enthusiasts to most likely engage in herding behavior. Their investment portfolio accounts for the highest share of innovative projects which are characterized by a particularly high degree of uncertainty. Moreover, Crowd Enthusiasts should be positively influenced by the project creators' expressed belief in the quality of the business idea. In the light of Crowd Enthusiasts' strong sense of community, this positive feeling may be reinforced when peers invest in the same project, eventually inducing the Crowd Enthusiasts to invest as well. In this respect, Casual Investors differ from Crowd Enthusiasts. Casual Investors pursue an investment strategy of riskdiversification among less innovative projects. With their investment decisions, they seem to rely on less ambiguous information which may not include the decision of other investors. Finally, Sophisticated Investors can be characterized as being more experienced and knowledgeable compared to Casual Investors and Crowd Enthusiasts. They tend to undertake thorough due diligence and primarily base their investment decisions on own knowledge and expertise. Therefore, we expect that investments of Sophisticated Investors are rather not influenced by others' investment decisions but instead are used for guidance, predominantly by Crowd Enthusiasts. The following hypothesis applies:

Hypothesis 4: Crowd Enthusiasts are more likely to follow the investment decisions of Sophisticated Investors than Casual Investors or Sophisticated Investors.

\subsection{Estimation strategy}

To test our hypotheses, we adopt a choice model (using probit regression) and investigate how crowdinvestors select a start-up project for funding from a set of alternatives. We implement a binary choice task that indicates whether or not the crowdinvestor decides to fund a particular project. Given that at any point in time there are multiple projects available for funding, we have to 
construct a temporal choice set for each crowdinvestor. Hence, for each instance when an investment is being made we identify the possible set of alternative projects, including the eventual choice. ${ }^{2}$ We let $Y_{i t}$ represent the binary choice task of funding a particular project out of the temporal set of alternative projects $i$, which is available at time $t$ representing the day of investment. ${ }^{3} Y_{i t}$ returns 1 if crowdinvestor $j$ decides to fund the particular project and 0 otherwise. It is important to note though that the binary choice task $Y_{i}$ may repeat over time. For example, the same investment alternatives are presented to different crowdinvestors if they access Companisto at the same time. Consequently, their investment decisions are likely to be correlated. This could potentially lead to biased estimates. To correct for the temporal correlation of outcomes in our data, we used the generalized estimation equation (GEE; Zeger et al. 1988) approach. Essentially, GEE is an extension of the generalized linear model (GLM) but allows for the use of a correlation matrix structure which takes into account the lack of independence of observations. The main advantage of GEE resides in the unbiased estimation of populationaveraged (marginal) regression coefficients despite possible misspecification of the correlation structure (Cui 2007). For our analysis, we used the commonly specified exchangeable correlation as the working correlation matrix.

As we are interested in the determinants of crowdinvestors' investment decisions, we let $\mu_{i t}=$ $E\left(Y_{i t}\right)$ denote the marginal expectation of whether a start-up project of the temporal choice set $i$ is funded in time $t$. The marginal expectation of investment depends on the vector of explanatory variables (project, creator, and crowdinvestor characteristics), $X_{i j}$, through the probit link function Probit $\left(\mu_{i t}\right)=X_{i j} \beta+v_{i}$, where $v_{i}$ represents the stochastic term related to the choice set $i$ which is assumed to be normally distributed.

Finally, common model selection criteria like Akaike's (1974) information criterion (AIC) cannot be applied as GEE is a quasi-likelihood-based method (Cui 2007). Pan (2001) proposed the independence model

\footnotetext{
${ }^{2}$ See Fig. 2 in the Appendix for a graphical illustration of the temporal overlap of projects' durations.

${ }^{3}$ While this approach takes investors' choice sets into account, we do not know, of course, whether investors indeed consider all available investment alternatives. In the same vein, our analysis does not take into account that investors may have investment opportunities outside of Companisto.
}

criterion (QIC) which is equivalent to the AIC in evaluating the goodness-of-fit of competing models.

\subsection{Measures}

\subsubsection{Dependent variable}

Our dependent variable is a dummy variable denoting whether a start-up project has been chosen for investment. The variable is coded as 1 if the project is chosen by the crowdinvestor and 0 otherwise.

\subsubsection{Explanatory variables}

We use three dummy variables indicating membership of a crowdinvestor to one of the three clusters: Casual Investors $(0=$ no, $1=$ yes $)$, Crowd Enthusiasts $(0=$ no, $1=$ yes), and Sophisticated Investors $(0=$ no, $1=$ yes $)$. The former cluster served as reference group.

Furthermore, we employ a set of explanatory variables to account for differences in the responses of the crowdinvestor types to signals of project quality and social influence, i.e., human capital of project creators, third-party certifications, financial projections and observed behavior of investor peers. The respective information has been collected from project pages at Companisto.

We use the educational level of project creators as a measure of human capital. Formal education may provide a broader set of knowledge, skills, and perspectives and may help mitigate the legitimacy problems start-ups face (Unger et al. 2011). Previous research showed that educational degrees of entrepreneurs, as part of their human capital, are a valid signal for a start-up's quality (Backes-Gellner and Werner 2007; Levie and Gimmon 2008; Ahlers et al. 2015; Nitani and Riding 2017; Piva and Rossi-Lamastra 2018). We use a PhD degree as a proxy for project creators' educational level. The corresponding dummy variable $P h D$ equals one if at least one member of the project team claims to possess a $\mathrm{PhD}$ degree.

Regarding third-party endorsement, both Shane and Stuart (2002) and Hsu (2007) found that previously established social ties with third parties, such as VCs or business angels, increased the chances of an entrepreneur receiving external financing. The central premise of this research is that start-ups may benefit from performance implications of affiliating with resource providers with established reputations. In the context 
of CI, Ralcheva and Roosenboom (2016) as well as Bapna (2019) employ connections with expert intermediaries in order to proxy external certification. Our dummy variable Ties returns 1 or 0 to indicate whether the start-up project has advertised a direct business or social relationship to a $\mathrm{VC}$ or angel investor before the start of the funding campaign.

The variable Financial forecast indicates whether a start-up project discloses financial projections to potential investors $(0=$ no, $1=$ yes $)$. The effect of disclosing financial forecasts has already been analyzed within franchising (Michael 2009) and with data from a CI platform (Ahlers et al. 2015). Since there is no standard procedure how to provide financial projections on Companisto, we consider statements in the project description about planned revenues, expenditures, earnings before interest and taxes as well as the return on sales.

Measures of social influence are typically based on the number of investors, the amount invested or specific investor types being present at a funding campaign within a defined period after the start of the campaign. For example, herding behavior is usually identified if one of the three measures of social influence positively correlates with a higher number of subsequent investors (cf. Colombo et al. 2015; Crosetto and Regner 2018; Hornuf and Schwienbacher 2018; Vismara 2018). The approach applied in this paper differs. We take the investor's perspective to determine the effect of peer investor behavior on the individual decision about which project to fund, accounting for all alternatives being present at the time of investment. Similarly, Lin et al. (2014), in their study on reward-based CF, measured the presence of rational herding by the number of a specific crowdfunder type that had already pledged when the focal crowdfunder was presented with the project choice. To account for the influence of observed peer behavior, the variable Sophisticated Investors_before measures the number of Sophisticated Investors that have already invested in the alternatives presented to each investor, at the point in time an investment decision is made.

\subsubsection{Control variables}

The regression analysis employs control variables which might potentially influence the investment decision of crowdinvestors. Lin et al. (2014) show that investors may back campaigns at a later funding stage in order to observe the behavior of other investors before they decide in which project to invest. Hence, the control variable Days after project start captures the number of days elapsed since the start of the campaign when the investment was made, relative to the total number of funding days of the campaign (multiplied by 100). We also control for the size of the founding team. Team size has been shown to positively affect external evaluations of the business idea (Foo et al. 2005), the investment decisions of VCs (Kirsch et al. 2009) and of crowdinvestors (Ahlers et al. 2015; Li et al. 2016; Vismara 2018). Therefore, the control variable Team members is a count of the members of the team of project creators. Moreover, we consider awards won, for example in business plan competitions, as a control variable to indicate external certifications of start-up quality. Winning an award may provide a positive evaluation of the business plan or the business idea, which mitigates information problems and eases the selection process for investors. We use a dummy variable to indicate whether a start-up project has received an award (Awards; $0=$ no, $1=$ yes). Prior research demonstrates that updates posted by the project creators can be an essential source of information leading to an increase in the number of pledges (Mollick 2014; Hornuf and Schwienbacher 2018; Block et al. 2018b). To control for this effect, the variable Updates takes the value 1 if at least one update was posted within 3 days before the investment decision of the focal crowdinvestor and 0 otherwise.

\subsection{Results}

Drawing upon the three crowdinvestor profiles that we identified in the cluster analysis (see Sect. 4.2), we now study how the evaluation of investment alternatives differs across investor types. In particular, we are interested in the individual responses of Casual Investors, Crowd Enthusiasts, and Sophisticated Investors to various signals of project quality and social influence when making investment choices. This analysis contributes to a more detailed understanding of the heterogeneity of crowdinvestors and their individual behavior on CI platforms.

For each investment made, we identify the possible set of alternative projects to invest in at that point of time. This results in a dataset with 67,833 investment alternatives. Table 3 provides descriptive statistics, and Table 4 displays the correlation among the variables used for the regression analysis. 
Table 3 Descriptive statistics for the variables used in the regression analysis

\begin{tabular}{|c|c|c|c|c|c|}
\hline Variables & Mean & SD & Min & Median & Max \\
\hline $\mathrm{PhD}$ & 0.12 & 0.32 & 0 & 0.00 & 1 \\
\hline Ties & 0.44 & 0.50 & 0 & 0.00 & 1 \\
\hline Financial forecast & 0.18 & 0.38 & 0 & 0.00 & 1 \\
\hline Sophisticated investors_before & 19.19 & 15.07 & 0 & 20.00 & 93 \\
\hline Days after project start & 45.71 & 30.63 & 0 & 45.00 & 100 \\
\hline Team members & 4.24 & 1.49 & 2 & 4.00 & 8 \\
\hline Awards & 0.15 & 0.36 & 0 & 0.00 & 1 \\
\hline Updates & 0.29 & 0.45 & 0 & 0.00 & 1 \\
\hline
\end{tabular}

$n$ of observations $=67,883$ investment alternatives presented to the crowdinvestors at the time of investment

Table 5 reports the results of the GEE estimation for the prediction of investment decisions of crowdinvestors. Model 1 is a baseline specification without considering our cluster variables. It can be regarded as a test whether we find support for the impact of human capital, third-party certifications, financial projections, and observed behavior of other investors in our sample without distinguishing investor types. The coefficients for $\operatorname{PhD}(\beta=0.491, p<0.001)$ and Financial forecast $(\beta=0.408, p<0.001)$ show up positive and significant. Crowdinvestors, in general, seem to take into consideration the educational attainment of project creators and the availability of financial forecasts as project quality signal when selecting among investment alternatives. In contrast, the likelihood to attract an investment seems to diminish if a start-up project has pre-existing relationships with traditional investors (Ties; $\beta=-0.0358, p<0.05$ ). The negative effect of Sophisticated Investors_before $(\beta=-0.0164$, $p<0.001)$ further suggests that crowdinvestors, in general, do not necessarily follow the investment decision of the group of Sophisticated Investors.

As regards the control variables, the team size (Team members; $\beta=0.176, p<0.001)$ as well as recently posted updates (Updates; $\beta=0.612, p<0.001$ ) significantly and positively predict funding of a project. The number of days since the funding campaign has started (Days after project start; $\beta=-0.0129, p<0.001$ ) and awards won (Awards; $\beta=-0.372, p<0.001$ ) seem to have a negative effect on the investment choice of crowdinvestors. Finally, Crowd Enthusiasts are relatively more likely to invest than Casual Investors, the reference group (Crowd Enthusiasts; $\beta=0.0678, p<0.001$ ), while there is no such difference between Sophisticated Investors and Casual Investors (Sophisticated Investors; $\beta=0.0102, n$. s.).

Next, models 2 to 5 in Table 5 focus on differences in the prediction of investment decisions across the distinct types of crowdinvestors in order to test hypotheses 1 to 4. Therefore, we include interaction effects between the

Table 4 Correlation matrix for the variables used in the regression analysis

\begin{tabular}{|c|c|c|c|c|c|c|c|c|}
\hline & Variables & {$[1]$} & {$[2]$} & {$[3]$} & [4] & {$[5]$} & {$[6]$} & {$[7]$} \\
\hline [1] & $\mathrm{PhD}$ & 1 & & & & & & \\
\hline [2] & Ties & -0.05 & 1 & & & & & \\
\hline [3] & Financial forecast & -0.17 & 0.20 & 1 & & & & \\
\hline [4] & Sophisticated investors_before & 0.17 & -0.25 & 0.15 & 1 & & & \\
\hline [5] & Days after project start & -0.09 & -0.02 & -0.11 & 0.12 & 1 & & \\
\hline [6] & Team members & 0.09 & 0.17 & 0.20 & 0.43 & -0.05 & 1 & \\
\hline [7] & Awards & 0.21 & 0.49 & 0.08 & -0.09 & -0.02 & 0.34 & 1 \\
\hline [8] & Updates & 0.03 & 0.22 & 0.13 & -0.22 & -0.34 & 0.03 & 0.07 \\
\hline
\end{tabular}

All correlations are significant at $p<0.05$ 
Table 5 Generalized estimation equation regressions for the prediction of investment decisions

\begin{tabular}{|c|c|c|c|c|c|}
\hline Variables & Model 1 & Model 2 & Model 3 & Model 4 & Model 5 \\
\hline \multicolumn{6}{|l|}{ Project quality signals } \\
\hline $\mathrm{PhD}$ & $0.491 * * *(24.22)$ & $0.329 * * *(13.68)$ & $0.453 * * *(22.04)$ & $0.489 * * *(24.16)$ & $0.365 * * *(18.15)$ \\
\hline Ties & $-0.036 *(-2.49)$ & $-0.046 * *(-3.24)$ & $0.071 * * *(4.36)$ & $-0.029 *(-2.03)$ & $-0.033 *(-2.32)$ \\
\hline Financial forecast & $0.408 * * *(26.58)$ & $0.447 * * *(28.95)$ & $0.423 * * *(27.69)$ & $0.474 * * *(26.02)$ & $0.495 * * *(31.32)$ \\
\hline \multicolumn{6}{|l|}{$\begin{array}{l}\text { Social influence of } \\
\text { investor peers }\end{array}$} \\
\hline Sophisticated investors_before & $\begin{array}{r}-0.016 * * * \\
(-31.55)\end{array}$ & $\begin{array}{r}-0.018 * * * \\
(-34.08)\end{array}$ & $\begin{array}{r}-0.017 * * * \\
\quad(-33.09)\end{array}$ & $\begin{array}{r}-0.017 * * * \\
(-31.99)\end{array}$ & $\begin{array}{r}-0.033 * * * \\
(-42.47)\end{array}$ \\
\hline \multicolumn{6}{|l|}{ Control variables } \\
\hline Days after project start & $\begin{array}{r}-0.013 * * * \\
(-52.00)\end{array}$ & $\begin{array}{r}-0.012 * * * \\
(-49.34)\end{array}$ & $\begin{array}{r}-0.013 * * * \\
\quad(-52.00)\end{array}$ & $\begin{array}{r}-0.013 * * * \\
(-52.06)\end{array}$ & $\begin{array}{r}-0.014 * * * \\
(-54.49)\end{array}$ \\
\hline Team members & $0.176 * * *(37.44)$ & $0.168 * * *(35.22)$ & $0.190 * * *(39.44)$ & $0.175 * * *(37.13)$ & $0.158 * * *(34.42)$ \\
\hline Awards & $\begin{array}{r}-0.372 * * * \\
\quad(-16.30)\end{array}$ & $\begin{array}{r}-0.331 * * * \\
\quad(-14.61)\end{array}$ & $\begin{array}{r}-0.350 * * * \\
\quad(-15.25)\end{array}$ & $\begin{array}{r}-0.370 * * * \\
\quad(-16.19)\end{array}$ & $\begin{array}{r}-0.335 * * * \\
(-15.00)\end{array}$ \\
\hline Updates & $0.612 * * *(45.37)$ & $0.609 * * *(44.92)$ & $0.605 * * *(44.66)$ & $0.611 * * *(45.46)$ & $0.572 * * *(41.99)$ \\
\hline \multicolumn{6}{|l|}{ Investor types } \\
\hline Crowd enthusiasts & $0.068 * * *(6.71)$ & $0.003(0.23)$ & $0.271 * * *(17.94)$ & $0.116 * * *(7.90)$ & $\begin{array}{r}-0.687 * * * \\
(-35.95)\end{array}$ \\
\hline Sophisticated investors & $0.010(0.48)$ & $-0.026(-1.03)$ & $0.150 * * *(4.15)$ & $0.000(0.01)$ & $\begin{array}{c}-0.397 * * * \\
(-9.87)\end{array}$ \\
\hline \multicolumn{6}{|l|}{ Hypothesis 1: } \\
\hline Crowd enthusiasts $\times \mathrm{PhD}$ & & $0.496 * * *(11.44)$ & & & \\
\hline Sophisticated investors $\times \mathrm{PhD}$ & & $0.272 * *(2.77)$ & & & \\
\hline \multicolumn{6}{|l|}{ Hypothesis 2: } \\
\hline Crowd enthusiasts $\times$ Ties & & & $\begin{array}{r}-0.437 * * * \\
(-14.67)\end{array}$ & & \\
\hline $\begin{array}{l}\text { Sophisticated investors } \times \\
\text { Ties }\end{array}$ & & & $\begin{array}{c}-0.242 * * * \\
(-4.01)\end{array}$ & & \\
\hline \multicolumn{6}{|l|}{ Hypothesis $3:$} \\
\hline $\begin{array}{l}\text { Crowd enthusiasts } \times \text { Financial } \\
\text { forecast }\end{array}$ & & & & $\begin{array}{c}-0.185^{* * * *} \\
(-6.24)\end{array}$ & \\
\hline $\begin{array}{l}\text { Sophisticated investors } \times \\
\text { Financial } \\
\text { forecast }\end{array}$ & & & & $0.020(0.31)$ & \\
\hline \multicolumn{6}{|l|}{ Hypothesis 4: } \\
\hline $\begin{array}{l}\text { Crowd enthusiasts } \times \text { Sophisticated } \\
\text { investors before }\end{array}$ & & & & & $0.034 * * *(38.10)$ \\
\hline $\begin{array}{l}\text { Sophisticated investors } \times \\
\text { Sophisticated } \\
\text { investors_before }\end{array}$ & & & & & $0.023 * * *(13.07)$ \\
\hline Constant & $\begin{array}{r}-1.086 * * * \\
(-53.96)\end{array}$ & $\begin{array}{r}-1.041 * * * \\
\quad(-50.87)\end{array}$ & $\begin{array}{r}-1.184 * * * \\
\quad(-55.82)\end{array}$ & $\begin{array}{r}-1.088 * * * \\
(-54.17)\end{array}$ & $\begin{array}{r}-0.697 * * * \\
(-30.75)\end{array}$ \\
\hline QIC & $57,461.488$ & $57,189.150$ & $57,330.856$ & $57,277.032$ & $55,069.290$ \\
\hline
\end{tabular}

$t$-statistics in parentheses. $n$ of observations $=67,883$ investment alternatives presented to the crowdinvestors at the time of investment $* p<0.05 ; * * p<0.01 ; * * * p<0.001$

cluster variables Casual Investors, Crowd Enthusiasts, and Sophisticated Investors on the one hand and the main explanatory variables $\mathrm{PhD}$ (model 2), Ties (model
3), Financial forecast (model 4), and Sophisticated Investors_before (model 5) on the other hand. The coefficients for the interaction effects are to be interpreted 
relative to the baseline group Casual Investors. Hence, they indicate how much larger or smaller the parameter estimates for the respective explanatory variables are for Crowd Enthusiasts and Sophisticated Investors relative to Casual Investors. Table 6 further allows for a more detailed analysis of the coefficients for the interaction effects. Here, corresponding to models 2 to 5 in Table 5 , the effect sizes for the parameter estimates of the main explanatory variables are reported. The effect size (see last column in Table 6) represents the percentage change in the predicted probability of a start-up project being chosen by an investor type before and after the value for the respective explanatory variable increased by one standard deviation (for continuous scales) or changed from 0 (base level) to 1 (for dummy variables), while keeping all other variables at their mean (for continuous scales) or median value (for dummy variables).

Turning to Hypothesis 1 and the proposed signaling effect of project creators' human capital on the likelihood to receive funding, model 2 in Table 5 provides positive and significant coefficients for Casual Investors $(\beta=0.329, p<0.001)$, Crowd Enthusiasts $(\beta=0.825$ $(0.329+0.496), p<0.001)$, and Sophisticated Investors $(\beta=0.601(0.329+0.272), p<0.01)$. Accordingly, it seems that higher levels of creator human capital are perceived as reliable project quality signal by all three crowdinvestor types. Interestingly, model 2 in Table 6 reveals significant differences among the three groups.
Accordingly, a change in the variable $\mathrm{PhD}$ from base level to 1 increases the likelihood that a project receives funding from the group of Crowd Enthusiasts by $213.76 \%$. For Sophisticated Investors, a project creator holding a $\mathrm{PhD}$ increases the likelihood of investment by $145.44 \%$, while the likelihood that Casual Investors choose a project is still $68.19 \%$ higher. In relative terms, however, Casual Investors are least likely to respond to higher levels of human capital in their investment decision. Therefore, hypothesis 1 is supported by the data. Moreover, our findings complement related results from other CI platforms stressing the importance of education (Ahlers et al. 2015; Nitani and Riding 2017; Piva and Rossi-Lamastra 2018).

Testing hypothesis 2 , model 3 takes account of the signaling effect of third-party endorsement by venture capitalists or business angels (Ties). We find significant interaction effects for Crowd Enthusiasts $(\beta=-0.437$, $p<0.001)$ and Sophisticated Investors $(\beta=-0.242$, $p<0.001$ ). Consequently, the coefficients for Crowd Enthusiasts and Sophisticated Investors are decreasing to $\beta=-0.366(p<0.001)$ and $\beta=-0.171(p<0.001)$, respectively. Crowd Enthusiasts and Sophisticated Investors seem to be less likely to invest in start-up projects when project creators possess preexisting ties to traditional investors. This is in strong contrast to Casual Investors $(\beta=0.071, p<0.001)$. Table 6 reveals that this group is $13.31 \%$ more likely to invest in a project if

Table 6 Predicted probabilities and effect size of coefficients

\begin{tabular}{|c|c|c|c|c|c|c|}
\hline \multirow[t]{2}{*}{ Model } & \multirow[t]{2}{*}{ Variables } & \multirow[t]{2}{*}{ Cluster } & \multirow[t]{2}{*}{ Coefficient } & \multicolumn{2}{|c|}{ Predicted probability } & \multirow[t]{2}{*}{ Effect size } \\
\hline & & & & Before & After & \\
\hline \multirow[t]{3}{*}{2} & \multirow[t]{3}{*}{$\mathrm{PhD}$} & Casual investors & $0.329 * *$ & 0.11 & 0.18 & $68.19 \%$ \\
\hline & & Crowd enthusiasts & $0.825^{* *}$ & 0.11 & 0.34 & $213.76 \%$ \\
\hline & & Sophisticated investors & $0.601 *$ & 0.10 & 0.25 & $145.44 \%$ \\
\hline \multirow[t]{3}{*}{3} & \multirow[t]{3}{*}{ Ties } & Casual investors & $0.071 * *$ & 0.10 & 0.11 & $13.31 \%$ \\
\hline & & Crowd enthusiasts & $-0.366^{* *}$ & 0.15 & 0.08 & $-46.40 \%$ \\
\hline & & Sophisticated investors & $-0.171 * *$ & 0.12 & 0.09 & $-25.48 \%$ \\
\hline \multirow[t]{3}{*}{4} & \multirow[t]{3}{*}{ Financial forecast } & Casual investors & $0.474 * *$ & 0.10 & 0.22 & $107.99 \%$ \\
\hline & & Crowd enthusiasts & $0.289 * *$ & 0.13 & 0.20 & $55.48 \%$ \\
\hline & & Sophisticated investors & $0.474 * *$ & 0.10 & 0.22 & $113.75 \%$ \\
\hline \multirow[t]{3}{*}{5} & \multirow[t]{3}{*}{ Sophisticated investors_before } & Casual investors & $-0.033^{* *}$ & 0.10 & 0.04 & $-61.84 \%$ \\
\hline & & Crowd enthusiasts & $0.002 * *$ & 0.10 & 0.10 & $4.75 \%$ \\
\hline & & Sophisticated investors & $-0.009 * *$ & 0.11 & 0.09 & $-21.87 \%$ \\
\hline
\end{tabular}

$n$ of observations $=67,883$ investment alternatives presented to the crowdinvestors at the time of investment

$* p<0.01 ; * * p<0.001$ 
there are existing relationships to external investors before the start of the funding campaign, while for Crowd Enthusiasts and Sophisticated Investors the likelihood to invest decreases by $46.4 \%$ and $25.48 \%$, respectively. Overall, we find support for our hypothesis 2.

In model 4, we investigate differences in investment activities of the investor types in response to the provision of financial forecasts (hypothesis 3 ). Table 5 indicates that Casual Investors and Sophisticated Investors share the same parameter estimate for Financial forecast $(\beta=0.474, p<0.001)$ since the interaction effect for Sophisticated Investors turns out not significant $(\beta=$ $0.0204, n$. s.). Thus, Casual Investors and Sophisticated Investors do not significantly differ in their response to provided financial forecasts. Table 6 further reveals that the likelihood to invest in projects increases for Casual Investors by $107.99 \%$ and for Sophisticated Investors by $113.75 \%$, respectively, if financial forecasts are provided. Moreover, examining the effect size of the coefficient for Crowd Enthusiasts $(\beta=0.289, p<0.001$ ), we find that a change of the dummy variable Financial forecast from base level to 1 increases the probability to invest in the focal project by $55.48 \%$. Taking these results together, we find strong support for the importance of financial information as project quality signal to reduce the degree of information asymmetry between project creators and investors. In more detail, though, Crowd Enthusiasts seem to be least likely to respond to this quality signal relative to the other two investor types. Hence, we find support for hypothesis 3 .

Finally, model 5 tests for different responses to observed peer behavior along the crowdinvestor typology (as proposed in hypothesis 4 ). Table 5 considers the interaction effects of the cluster membership variables and the explanatory variable Sophisticated Investors_before. The coefficient for Casual Investors is negative and statistically significant $(\beta=-0.0326$, $p<0.001$ ), revealing that Casual Investors are less likely to follow more sophisticated peers in their investment decision. Assessing the economic magnitude of the coefficient in Table 6, a one standard deviation increase in the number of Sophisticated Investors that have already invested in a project (i.e., an increase from 20 to 35 Sophisticated Investors) leads to a decrease in the likelihood that Casual Investors will choose the same project by $61.84 \%$. Similarly, for Sophisticated Investors, the likelihood to invest decreases by $21.87 \%$ ( $\beta=$ $-0.009, p<0.001)$ if the variable Sophisticated
Investors_before is increased by one standard deviation. In contrast, the coefficient of the interaction effect for Crowd Enthusiasts is positive and statistically significant (see Table $5 ; \beta=0.034, p<0.001$ ) and even large enough to turn the negative coefficient of the baseline group from $\beta=-0.033(p<0.001)$ to $\beta=0.002$ $(p<0.001)$. In economic terms, Table 6 suggests that a one standard deviation increase of Sophisticated Investors_before leads to an increase in the likelihood that Crowd Enthusiasts will choose the project by $4.75 \%$. Supporting hypothesis 4, Crowd Enthusiasts seem to be more likely to follow the investment decision of their more experienced and knowledgeable peers than the groups of Sophisticated Investors and Casual Investors, even though the economic magnitude of this response is rather small. Another important caveat for this result is the first-come, first-serve mechanism adopted by Companisto. As the funding mechanism induces quick investments at the early stages of a funding campaign, it may even impede herding behavior. Investors might feel inclined to invest early, forgoing the possibility to wait and observe the decision of others first.

\subsection{Robustness check}

Building on the robustness check of our cluster analysis that confirmed our typology of crowdinvestors with a sample restricted to the first nine, 12 and 14 projects we now test the robustness of our regression results. We start with a subsample that includes the last ten projects and add further projects one by one in order to see, whether regression results remain qualitatively equal to the full sample when only these observations are considered. While the regression model does not converge when the restricted sample includes only the last 16 projects or less, our results are confirmed when the restricted sample excludes the first 11 projects (or less). Coefficient signs and significance levels are the same as in the entire sample results for all main and interaction effects.

\section{Discussion}

Given the recent rise of crowdfunding, especially crowdinvesting (CI), this paper aims to contribute to a more thorough understanding of the "crowd." We identify distinct investor types with different investment strategies and motivations. Consequently, we assess 
the decision-making process of these individual investor types regarding the selection of investment opportunities, while accounting for the importance of project quality signals and social influence concerning the funding behavior of other investors.

Our analysis identifies three different crowdinvestor types: a relatively small group of very active and experienced funders (the Sophisticated Investors), a sizable group of funders that are motivated by pro-social/community factors (the Crowd Enthusiasts), while the majority of funders seems mostly concerned about monetary returns (the Casual Investors).

These findings add to the literature that regards the crowd as a heterogeneous community and aims to identify differences in behavior (Hornuf and Schmitt 2016; Hervé et al. 2019; Mohammadi and Shafi 2018; Günther et al. 2018). With respect to crowdinvestors' motivations, our results confirm previous research that crowdfunders are not exclusively motivated by financial returns but also by pro-social or community motives (Gerber et al. 2012; Belleflamme et al. 2014; Bretschneider and Leimeister 2017). Our results suggest that a sizable "pro-social" type not only exists in rewardbased CF (see Lin et al. 2014) but also in the domain of CI.

In the second stage of our analysis, we take these insights about distinct crowdinvestor types to the investment level in order to study individual choices. We test crowdinvestors' response to project quality signals previously established by existing studies (Ahlers et al. 2015; Li et al. 2016; Ralcheva and Roosenboom 2016; Nitani and Riding 2017; Piva and Rossi-Lamastra 2018; Bapna 2019) without distinguishing by investor types.

First, this individual-level analysis complements other studies methodologically as they are mostly performed at the project level. Second, our analysis reveals that only human capital appears to be a general signal among the crowd. While investor type-specific effect sizes differ significantly, they are all positive. Instead, external certifications seem to be a signal that is only considered by Casual Investors. Also financial projections do not seem to be a universal signal for the crowd as Crowd Enthusiasts do not respond to them.

Moreover, our findings show that the majority of investors, i.e., the group of Casual Investors, do not seem inclined to follow the investment decisions of more sophisticated investors. At first glance, this result appears to contradict the findings of Vismara (2018): at the platform Crowdcube investors with a public profile play a crucial role in triggering information cascades. Possibly, investors who possess superior knowledge are not salient enough at Companisto in order to make other investors rely on their funding decisions. We verified this with information about crowdinvestors' membership in the Companisto Business Club. A badge next to an investor's name indicates membership in the club. As we do not have data about membership directly we use the underlying ranking (the top $10 \%$ of ranked investors are awarded membership). ${ }^{4}$ Checking the overlap between the ranking data and our classification of investors shows that Sophisticated Investors are indeed relatively overrepresented among the top $10 \%$ of ranked investors. However, membership is not exclusive to Sophisticated Investors, also many Crowd Enthusiasts and Casual Investors are club members. Thus, being a Sophisticated Investor is not a signal that can be clearly observed, a possible explanation for the lack of information cascades.

These insights about the heterogeneous composition of crowdinvestors, their motivations to fund a campaign and their response to quality signals as well as peer behavior should be of interest for managers of CI platforms and entrepreneurs alike. This has implications for the design choices at CI platforms as they may affect the investment behavior of its participating investors. The trade-off between investor protection and start-up stimulation under current securities regulation of equitybased CF is well recognized (see Bradford 2012; Griffin 2013; Hornuf and Schwienbacher 2017). Policy intervention can achieve increased protection, for example, by setting standards for the provision of adequate information by entrepreneurs and platforms. A promising alternative avenue to decrease the potential abuse of less sophisticated investors may well be to improve platform design and alleviate information transmission from knowledgeable investors to the crowd. Our results confirm that sophisticated investors are a part of the crowd, see also Abrams (2017) for related evidence. Therefore, the pre-requisites appear to exist for beneficial knowledge spillovers within the crowd.

Naturally, our study is not without limitations. First of all, as noted by Lin et al. (2014), over time learning most likely will take place. As a consequence, more and

\footnotetext{
${ }^{4}$ Companisto ranks investors depending on the number of start-ups in the portfolio, the money invested and the completeness of the profile, among other factors.
} 
more Casual Investors may gain experience and might evolve into Sophisticated Investors. Our study is a snapshot at a relatively early point of time in the life of a CI platform. Thus, the fraction of Casual Investors should be regarded as an upper bound, while the fraction of Sophisticated Investors is likely to be a lower bound. A study at a more advanced point of time of a platform would provide valuable insights to what extent an evolution of types occurs.

Moreover, our cluster analysis is only one possible methodological approach to get insights about investor motivation. An alternative way to find out about the motivation of participating investors would be a qualitative survey analysis (e.g., Gerber et al. 2012, or Bretschneider and Leimeister 2017, in the context of reward-based $\mathrm{CF}$ ). This would require interviewing investors about their motivation and potentially a more extensive range of variables concerning signaling mechanisms and social influence could be used. Such research would be a valuable complement to the methodological approach of our study.

Funding Information Open Access funding provided by Projekt DEAL.

\section{Appendix}

Table 7 Background information about the start-up projects

\begin{tabular}{|c|c|c|c|c|c|c|c|c|c|}
\hline No. & Start-up project & Start date & End date & $\begin{array}{l}\text { Funding } \\
\text { goal }\end{array}$ & $\begin{array}{l}\text { Total } \\
\text { funding }\end{array}$ & $\begin{array}{l}\text { Total } \\
\text { funding } \\
\text { days }\end{array}$ & Investors & Sector & Business idea \\
\hline 1 & Doxter & 6.6.2012 & 9.9.2012 & 25,000 & 100,000 & 96 & 392 & Technology & $\begin{array}{l}\text { Internet platform to book } \\
\text { medical appointments online }\end{array}$ \\
\hline 2 & ePortrait & 22.8 .2012 & 11.9.2012 & 25,000 & 100,000 & 21 & 377 & Technology & $\begin{array}{l}\text { Online service for creating } \\
\text { biometric passport photos }\end{array}$ \\
\hline 3 & Ludufactur & 31.8 .2012 & 1.11 .2012 & 25,000 & 50,000 & 63 & 366 & Technology & $\begin{array}{l}\text { Customization of card and } \\
\text { board games for the gift } \\
\text { market }\end{array}$ \\
\hline 4 & Movinary & 30.9 .2012 & 12.11.2012 & 25,000 & 100,000 & 44 & 395 & Technology & $\begin{array}{l}\text { Online service for creating } \\
\text { videos from images }\end{array}$ \\
\hline 5 & BetterTaxi & 1.11 .2012 & 4.12 .2012 & 25,000 & 100,000 & 34 & 445 & Technology & $\begin{array}{l}\text { Mobile application for booking } \\
\text { taxis via smartphone }\end{array}$ \\
\hline 6 & livekritik.de & 22.11 .2012 & 22.3 .2013 & 25,000 & 80,525 & 121 & 496 & Technology & $\begin{array}{l}\text { Online platform collecting } \\
\text { reports and visitors reviews } \\
\text { about cultural events such as } \\
\text { stage plays, concerts, dance } \\
\text { or readings }\end{array}$ \\
\hline 7 & Meine-Spielzeugkiste & 6.1 .2013 & 17.1.2013 & 25,000 & 100,000 & 12 & 356 & Retail & $\begin{array}{l}\text { Rental subscription model } \\
\text { enabling parents to borrow } \\
\text { children's toys without } \\
\text { having to buy them }\end{array}$ \\
\hline 8 & swabr.com & 4.2.2013 & 4.4.2013 & 25,000 & 55,640 & 60 & 406 & Technology & $\begin{array}{l}\text { Enterprise social network } \\
\text { service for communications } \\
\text { within a company }\end{array}$ \\
\hline 9 & SponsoRun & 25.2 .2013 & 25.4 .2013 & 25,000 & 73,935 & 60 & 421 & Technology & $\begin{array}{l}\text { Mobile application that rewards } \\
\text { sportive activity with } \\
\text { exclusive vouchers }\end{array}$ \\
\hline 10 & Tame & 18.3.2013 & 12.4 .2013 & 25,000 & 250,000 & 26 & 736 & Technology & $\begin{array}{l}\text { Context search engine in } \\
\text { real-time for Twitter }\end{array}$ \\
\hline 11 & Foodist & 11.4 .2013 & 11.5.2013 & 25,000 & 175,000 & 31 & 550 & Retail & $\begin{array}{l}\text { Monthly subscription service } \\
\text { that delivers a collection of } \\
\text { gourmet products }\end{array}$ \\
\hline 12 & SongFor & 6.5 .2013 & 5.7 .2013 & 25,000 & 41,290 & 60 & 264 & Technology & $\begin{array}{l}\text { Online platform that enables } \\
\text { users to personalize their } \\
\text { music playlists by relating } \\
\text { songs with their emotions } \\
\text { and experiences }\end{array}$ \\
\hline 13 & $\begin{array}{l}5 \text { CUPS and some } \\
\text { sugar }\end{array}$ & 3.6.2013 & 2.7.2013 & 25,000 & 300,000 & 30 & 688 & Food & $\begin{array}{l}\text { Sells, manufactures and delivers } \\
\text { customized and personalized }\end{array}$ \\
\hline
\end{tabular}


Table 7 (continued)

\begin{tabular}{lllll}
\hline No. Start-up project Start date End date & $\begin{array}{l}\text { Funding } \\
\text { goal }\end{array}$ & $\begin{array}{l}\text { Total } \\
\text { funding funding } \\
\text { days }\end{array}$ & $\begin{array}{l}\text { Total Investors Sector } \\
\text { Business idea }\end{array}$
\end{tabular}

\begin{tabular}{|c|c|c|c|c|c|c|c|c|c|}
\hline & & & & & & & & & $\begin{array}{l}\text { tea blends which customers } \\
\text { create online }\end{array}$ \\
\hline 14 & OnlineVersicherung.de & 20.6 .2013 & 10.9.2013 & 50,000 & 300,000 & 83 & 702 & Services & Online insurance broker \\
\hline 15 & Wunsch-Brautkleid & 8.7 .2013 & 15.8.2013 & 25,000 & 158,485 & 39 & 427 & Retail & $\begin{array}{l}\text { Online marketplace for new, } \\
\text { used, and customized } \\
\text { wedding dresses }\end{array}$ \\
\hline 16 & Zapitano & 22.7 .2013 & 20.10 .2013 & 50,000 & 106,895 & 91 & 454 & Technology & $\begin{array}{l}\text { Web-based social TV } \\
\text { application that enables users } \\
\text { to share and comment on TV } \\
\text { shows }\end{array}$ \\
\hline 17 & sporTrade & 19.8.2013 & 11.10 .2013 & 25,000 & 100,000 & 54 & 392 & Retail & $\begin{array}{l}\text { Online marketplace for new and } \\
\text { used sporting goods }\end{array}$ \\
\hline 18 & Wonderpots & 2.9 .2013 & 9.9 .2013 & 50,000 & 500,000 & 8 & 774 & Food & $\begin{array}{l}\text { Low-calorie ice cream made } \\
\text { from yoghurt }\end{array}$ \\
\hline 19 & Sommelier Privé & 16.9.2013 & 12.12 .2013 & 25,000 & 300,000 & 88 & 672 & Food & Online wine shop \\
\hline 20 & Lizzar & 30.9 .2013 & 30.11 .2013 & 25,000 & 50,995 & 62 & 337 & Technology & $\begin{array}{l}\text { Streaming service and digital } \\
\text { music store for independent } \\
\text { music }\end{array}$ \\
\hline 21 & Schnuff \& Co & 14.10.2013 & 13.12 .2013 & 25,000 & 67,785 & 61 & 351 & Services & $\begin{array}{l}\text { Internet platform for pet care } \\
\text { services }\end{array}$ \\
\hline 22 & BiteBox & 2.12 .2013 & 20.2 .2014 & 25,000 & 500,000 & 81 & 1094 & Retail & $\begin{array}{l}\text { Sells and delivers snack items } \\
\text { online }\end{array}$ \\
\hline 23 & Nichtraucher.de & 6.1 .2014 & 5.4 .2014 & 25,000 & 164,980 & 90 & 552 & Services & $\begin{array}{l}\text { Online marketplace for } \\
\text { smoking cessation services }\end{array}$ \\
\hline 24 & Readfy & 4.2 .2014 & 24.3.2014 & 25,000 & 500,000 & 49 & 1154 & Technology & $\begin{array}{l}\text { Mobile application for free } \\
\text { ad-financed reading of } \\
\text { eBooks }\end{array}$ \\
\hline 25 & fotovio & 10.3 .2014 & 10.6 .2014 & 25,000 & 148,640 & 93 & 601 & Technology & $\begin{array}{l}\text { Mobile application for creating } \\
\text { and sending QR Code based } \\
\text { personal video messages }\end{array}$ \\
\hline 26 & Kyl & 10.4 .2014 & 10.8 .2014 & 50,000 & 940,650 & 123 & 1621 & Food & Molecular ice cream \\
\hline 27 & MyParfum & 28.4 .2014 & 28.8 .2014 & 25,000 & 443,995 & 123 & 941 & Services & $\begin{array}{l}\text { Internet platform that enables } \\
\text { customers to create } \\
\text { individualized fragrances } \\
\text { online }\end{array}$ \\
\hline 28 & Knicket & 10.6 .2014 & 10.10 .2014 & 25,000 & 263,765 & 123 & 702 & Technology & $\begin{array}{l}\text { Search engine for mobile } \\
\text { applications }\end{array}$ \\
\hline
\end{tabular}

Fig. 1 Dendrogram using Ward's method. The dissimilarity measure is based on the Euclidean distance between the different clusters

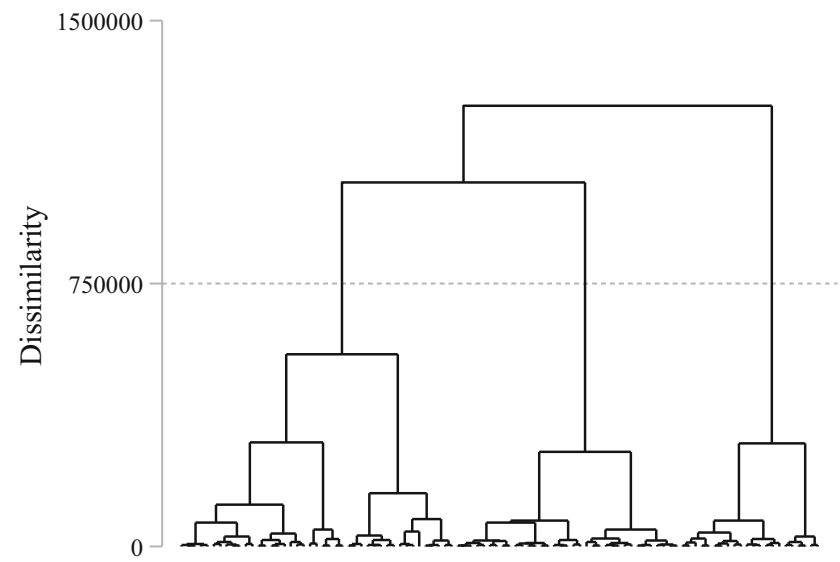




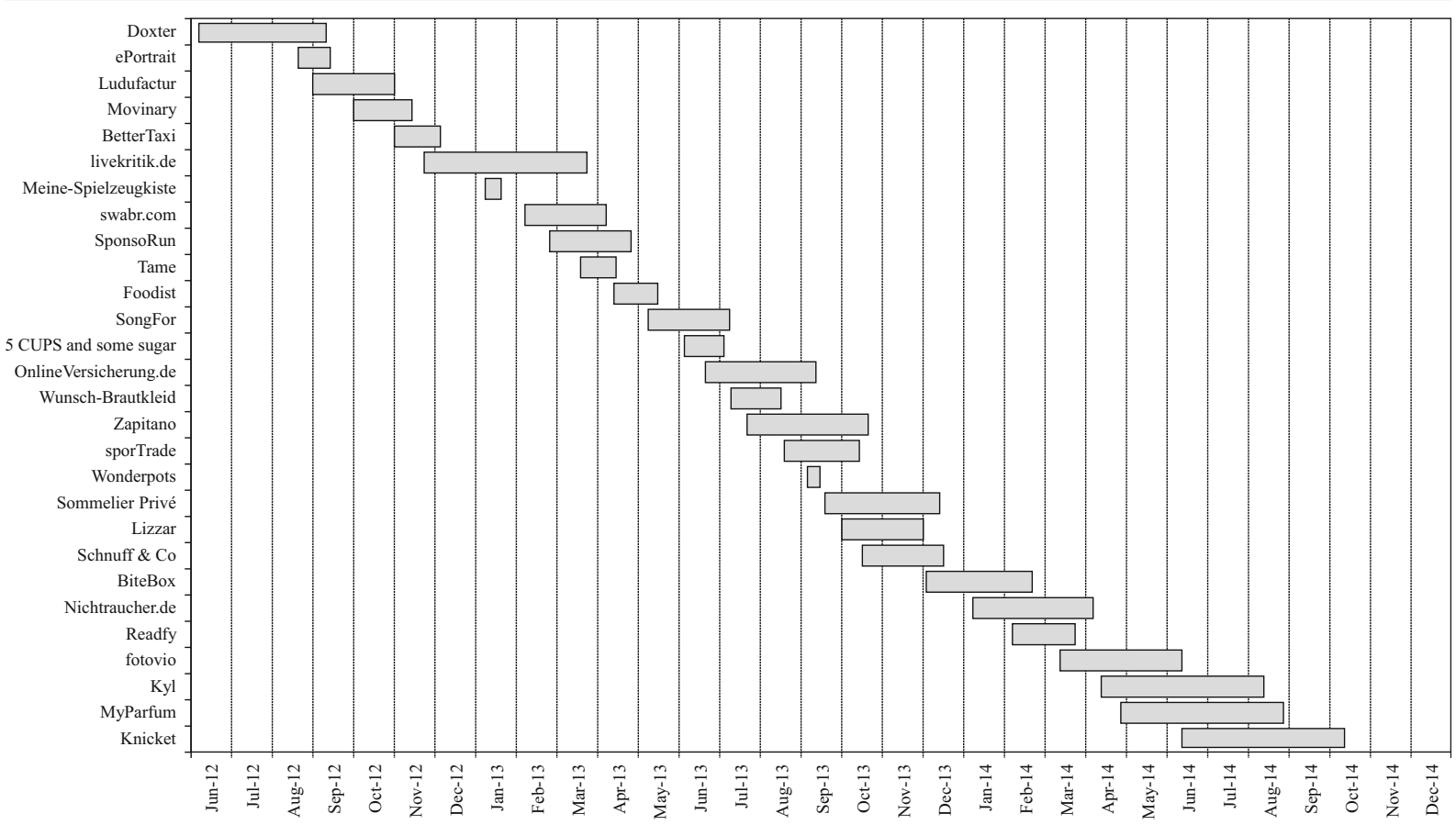

Fig. 2 Funding history of the start-up projects. Funding duration in total funding days

Open Access This article is licensed under a Creative Commons Attribution 4.0 International License, which permits use, sharing, adaptation, distribution and reproduction in any medium or format, as long as you give appropriate credit to the original author(s) and the source, provide a link to the Creative Commons licence, and indicate if changes were made. The images or other third party material in this article are included in the article's Creative Commons licence, unless indicated otherwise in a credit line to the material. If material is not included in the article's Creative Commons licence and your intended use is not permitted by statutory regulation or exceeds the permitted use, you will need to obtain permission directly from the copyright holder. To view a copy of this licence, visit http://creativecommons.org/licenses/by/4.0/.

\section{References}

Abrams, E. (2017), Securities crowdfunding: More than family, friends, and fools? SSRN working paper, Retrieved from https://ssrn.com/abstract=2902217. Accessed 30 Apr 2019.

Agrawal, A., Catalini, C., \& Goldfarb, A. (2014). Some simple economics of crowdfunding. Innovation Policy and the Economy, 14(1), 63-97.

Ahlers, G. K., Cumming, D., Günther, C., \& Schweizer, D. (2015). Signaling in equity crowdfunding. Entrepreneurship Theory and Practice, 39(4), 955-980.

Akaike, H. (1974). A new look at statistical model identification. IEEE Transactions on Automatic Control, AC-19, 716-723.
Backes-Gellner, U., \& Werner, A. (2007). Entrepreneurial signaling via education: A success factor in innovative start-ups. Small Business Economics, 29(1-2), 173-190.

Bapna, S. (2019). Complementarity of signals in early-stage equity investment decisions: Evidence from a randomized field experiment. Management Science, 65(2), 933-952.

Baum, J. A., \& Silverman, B. S. (2004). Picking winners or building them? Alliance, intellectual, and human capital as selection criteria in venture financing and performance of biotechnology startups. Journal of Business Venturing, 19(3), 411-436.

Becker, G. S. (1964). Human capital: A theoretical and empirical analysis, with special reference to education. Chicago: The University of Chicago Press.

Belleflamme, P., Lambert, T., \& Schwienbacher, A. (2014). Crowdfunding: Tapping the right crowd. Journal of Business Venturing, 29(5), 585-609.

Block, J., Colombo, M., Cumming, D., \& Vismara, S. (2018a). New players in entrepreneurial finance and why they are there. Small Business Economics, 50, 239-250.

Block, J., Hornuf, L., \& Moritz, A. (2018b). Which updates during an equity crowdfunding campaign increase crowd participation? Small Business Economics, 50(1), 3-27.

Bradford, C. S. (2012). Crowdfunding and the federal securities law. Columbia Business Law Review, 2012(1), 1-150.

Bretschneider, U., \& Leimeister, J. M. (2017). Not just an ego-trip: Exploring backers' motivation for funding in incentive-based crowdfunding. The Journal of Strategic Information Systems, 26(4), 246-260.

Bruton, G., Khavul, S., Siegel, D., \& Wright, M. (2015). New financial alternatives in seeding entrepreneurship: 
Microfinance, crowdfunding, and peer-to-peer innovations. Entrepreneurship Theory and Practice, 39(1), 9-26.

Burtch, G., Ghose, A., \& Wattal, S. (2013). An empirical examination of the antecedents and consequences of contribution patterns in crowd-funded markets. Information Systems Research, 24(3), 499-519.

Carpenter, R. E., \& Petersen, B. C. (2002). Capital market imperfections, high-tech investment, and new equity financing. The Economic Journal, 112(477), F54-F72.

Cassar, G. (2004). The financing of business start-ups. Journal of Business Venturing, 19(2), 261-283.

Cholakova, M., \& Clarysse, B. (2015). Does the possibility to make equity investments in crowdfunding projects crowd out reward-based investments? Entrepreneurship Theory and Practice, 39(1), 145-172.

Colombo, M. G., Franzoni, C., \& Rossi-Lamastra, C. (2015). Internal social capital and the attraction of early contributions in crowdfunding. Entrepreneurship Theory and Practice, 39(1), 75-100.

Colombo, M. G., \& Grilli, L. (2007). Funding gaps? Access to bank loans by high-tech start-ups. Small Business Economics, 29(1-2), 25-46.

Crosetto, P., \& Regner, T. (2018). It's never too late: Funding dynamics and self pledges in reward-based crowdfunding. Research Policy, 47(8), 1463-1477.

Crowdfunding-Monitor (2017). Crowdfunding-Monitor: Daten, Zahlen und Fakten zum Markt. Retrieved from http://www. fuer-gruender.de/kapital/eigenkapital/crowdfunding/monitor/.

Cui, J. (2007). QIC program and model selection in GEE analyses. The Stata Journal, 7(2), 209-220.

Daskalakis, N., \& Yue, W. (2017). User's perceptions of motivations and risks in crowdfunding with financial returns. SSRN Working Paper, retrieved from https://ssrn. com/abstract $=2968912$.

Epstein, L. G., \& Schneider, M. (2008). Ambiguity, information quality, and asset pricing. The Journal of Finance, 63(1), 197-228.

Foo, M. D., Wong, P. K., \& Ong, A. (2005). Do others think you have a viable business idea? Team diversity and judges' evaluation of ideas in a business plan competition. Journal of Business Venturing, 20(3), 385-402.

Freear, J., Sohl, J. E., \& Wetzel Jr., W. E. (1994). Angels and nonangels: Are there differences? Journal of Business Venturing, $9(2), 109-123$.

Galak, J., Small, D., \& Stephen, A. T. (2011). Microfinance decision making: A field study of prosocial lending. Journal of Marketing Research, 48(Special Issue), 130-137.

Gerber, E. M., Hui, J. S., \& Kuo, P. Y. (2012). Crowdfunding: Why people are motivated to post and fund projects on crowdfunding platforms. Proceedings of the international workshop on design, influence, and social technologies: Techniques, Impacts and Ethics.

Giudici, G., Guerini, M., \& Rossi-Lamastra, C. (2018). Rewardbased crowdfunding of entrepreneurial projects: The effect of local altruism and localized social capital on proponents' success. Small Business Economics, 50(2), 307-324.

Gleasure, R., \& Feller, J. (2016). Emerging technologies and the democratisation of financial services: A metatriangulation of crowdfunding research. Information and Organization, 26(4), 101-115.
Gompers, P., \& Lerner, J. (2001). The venture capital revolution. Journal of Economic Perspectives, 15(2), 145-168.

Griffin, Z. J. (2013). Crowdfunding: Fleecing the American masses. Journal of Law, Technology \& the Internet, 4, 375410.

Günther, C., Johan, S., \& Schweizer, D. (2018). Is the crowd sensitive to distance? How investment decisions differ by investor type. Small Business Economics, 50(2), 289-305.

Hekman, E., \& Brussee, R. (2013). Crowdfunding and online social networks, 2nd Consortium on Applied Research and Professional Education. Manchester, UK.

Hervé, F., Manthé, E., Sannajust, A., \& Schwienbacher, A. (2019). Determinants of individual investment decisions in investment-based crowdfunding. Journal of Business Finance \& Accounting, 46(5-6), 762-783.

Herzenstein, M., Dholakia, U. M., \& Andrews, R. L. (2011). Strategic herding behavior in peer-to-peer loan auctions. Journal of Interactive Marketing, 25(1), 27-36.

Hildebrand, T., Puri, M., \& Rocholl, J. (2017). Adverse incentives in crowdfunding. Management Science, 63(3), 587-608.

Hornuf, L. \& Schmitt, M. (2016). Does a local bias exist in equity crowdfunding? The impact of investor types and portal design. SSRN Working Paper, Retrieved from https://ssrn. com/abstract=2801170. Accessed 30 Apr 2019.

Hornuf, L., \& Schwienbacher, A. (2016). Crowdinvesting: Angel investing for the masses? In H. Landström \& C. Mason (Eds.), Handbook of research on business angels (pp. 381397). Cheltenham, UK: Edward Elgar Publishing.

Hornuf, L., \& Schwienbacher, A. (2017). Should securities regulation promote equity crowdfunding? Small Business Economics, 49(3), 579-593.

Hornuf, L., \& Schwienbacher, A. (2018). Market mechanisms and funding dynamics in equity crowdfunding. Journal of Corporate Finance, 50, 556-574.

Hsu, D. H. (2007). Experienced entrepreneurial founders, organizational capital, and venture capital funding. Research Policy, 36(5), 722-741.

Ireland, R. D., Hitt, M. A., \& Sirmon, D. G. (2003). A model of strategic entrepreneurship: The construct and its dimensions. Journal of Management, 29(6), 963-989.

Jiang, M. F., Tseng, S. S., \& Su, C. M. (2001). Two-phase clustering process for outliers detection. Pattern Recognition Letters, 22(6-7), 691-700.

Ketchen, D. J., \& Shook, C. L. (1996). The application of cluster analysis in strategic management research: An analysis and critique. Strategic Management Journal, 17(6), 441-458.

Kim, K., \& Viswanathan, S. (2018). The experts in the crowd: The role of reputable investors in a crowdfunding market. SSRN Working Paper, Retrieved from https://ssrn. com/abstract=2258243. Accessed 30 Apr 2019.

Kirsch, D., Goldfarb, B., \& Gera, A. (2009). Form or substance: The role of business plans in venture capital decision making. Strategic Management Journal, 30(5), 487-515.

Kortleben, H., \& Vollmar, B. H. (2012). Crowdinvesting: Eine Alternative in der Gründungsfinanzierung? PFH Research Papers, No. 2012/06, Retrieved from http://hdl.handle. net/10419/71298. Accessed 30 Apr 2019.

Kraut, R. E., \& Resnick, P. (2011). Encouraging contributions to online communities. In R. E. Kraut \& P. Resnick (Eds.), Building successful online communities: Evidence-based social design (pp. 21-76). Cambridge: MIT Press. 
Le Pendeven, B. (2016). Equity crowdfunding: Impact of the innovation degree on fundraising campaigns. ICIE 2016 Proceedings of the 4 th International Conference on Innovation and Entrepreneurship.

Lee, E., \& Lee, B. (2012). Herding behavior in online P2P lending: An empirical investigation. Electronic Commerce Research and Applications, 11(5), 495-503.

Levie, J., \& Gimmon, E. (2008). Mixed signals: Why investors may misjudge first time high technology venture founders. Venture Capital, 10(3), 233-256.

Li, X., Tang, Y., Yang, N., Ren, R., Zheng, H., \& Zhou, H. (2016). The value of information disclosure and lead investor in equity-based crowdfunding: An exploratory empirical study. Nankai Business Review International, 7(3), 301-321.

Lin, Y., Boh, W. F., \& Goh, K. H. (2014). How different are crowdfunders? Examining archetypes of crowdfunders and their choice of projects. Academy of Management Proceedings, 2014(1), 13309.

Massolution (2016). Crowdfunding Industry Report. Retrieved from http://reports.crowdsourcing.org/index.php?route= product/product\&product_id=54. Accessed 30 Apr 2019.

Michael, S. C. (2009). Entrepreneurial signaling to attract resources: The case of franchising. Managerial and Decision Economics, 30(6), 405-422.

Milligan, G. W. (1980). An examination of the effect of six types of error perturbation on fifteen clustering algorithms. Psychometrika, 45(3), 325-342.

Milligan, G. W., \& Cooper, M. C. (1985). An examination of procedures for determining the number of clusters in a data set. Psychometrika, 50(2), 159-179.

Mochkabadi, K., \& Volkmann, C. K. (2018). Equity crowdfunding: A systematic review of the literature. Small Business Economics. https://doi.org/10.1007/s11187-0180081-x.

Mohammadi, A., \& Shafi, K. (2018). Gender differences in the contribution patterns of equity-crowdfunding investors. Small Business Economics, 50(2), 275-287.

Mollick, E. (2014). The dynamics of crowdfunding: An exploratory study. Journal of Business Venturing, 29(1), 1-16.

Moysidou, K., \& Spaeth, S. (2016). Cognition, emotion and perceived values in crowdfunding decision-making. Paper presented at the Open and User Innovation Conference, Boston, USA.

Nitani, M., \& Riding, A. (2017). On crowdfunding success: Firm and owner attributes and social networking. SSRN working paper, Retrieved from https://ssrn.com/abstract=2945081. Accessed 30 Apr 2019.

Pan, W. (2001). Akaike's information criterion in generalized estimating equations. Biometrics, 57(1), 120-125.
Piva, E., \& Rossi-Lamastra, C. (2018). Human capital signals and entrepreneurs' success in equity crowdfunding. Small Business Economics, 51(3), 667-686.

Punj, G., \& Stewart, D. W. (1983). Cluster analysis in marketing research: Review and suggestions for application. Journal of Marketing Research, 20(2), 134-148.

Ralcheva, A., \& Roosenboom, P. (2016). On the road to success in equity crowdfunding. SSRN Working Paper, Retrieved from https://ssrn.com/abstract=2727742. Accessed 30 Apr 2019.

Ryu, S., \& Kim, Y. G. (2016). A typology of crowdfunding sponsors: Birds of a feather flock together? Electronic Commerce Research and Applications, 16, 43-54.

Shane, S., \& Stuart, T. (2002). Organizational endowments and the performance of university start-ups. Management Science, 48(1), 154-170.

Unger, J. M., Rauch, A., Frese, M., \& Rosenbusch, N. (2011). Human capital and entrepreneurial success: a meta-analytical review. Journal of Business Venturing, 26(3), 341-358.

Vismara, S. (2016). Equity retention and social network theory in equity crowdfunding. Small Business Economics, 46, 579590.

Vismara, S. (2018). Information cascades among investors in equity crowdfunding. Entrepreneurship Theory and Practice, 42(3), 467-497.

Vismara, S. (2019). Sustainability in equity crowdfunding. Technological Forecasting and Social Change, 141, 98-106.

Vulkan, N., Åstebro, T., \& Sierra, M. F. (2016). Equity crowdfunding: A new phenomena. Journal of Business Venturing Insights, 5, 37-49.

Wallmeroth, J. (2019). Investor behavior in equity crowdfunding. Venture Capital, 21(2-3), 273-300.

Wong, A., Bhatia, M., \& Freeman, Z. (2009). Angel finance: The other venture capital. Strategic Change, 18(7-8), 221-230.

Zacharakis, A. L., \& Meyer, G. D. (2000). The potential of actuarial decision models: Can they improve the venture capital investment decision? Journal of Business Venturing, 15(4), 323-346.

Zhang, J., \& Liu, P. (2012). Rational herding in microloan markets. Management Science, 58(5), 892-912.

Zeger, S. L., Liang, K. Y., \& Albert, P. S. (1988). Models for longitudinal data: a generalized estimating equation approach. Biometrics, 1049-1060.

Publisher's note Springer Nature remains neutral with regard to jurisdictional claims in published maps and institutional affiliations. 